\title{
Textos
}

\section{María Campo Alange sobre María Blanchard ${ }^{1}$ María Campo Alange about María Blanchard}

\section{Su arte}

Es allí en el estudio de la calle Boulard donde pinta sus mejores lienzos. Allí donde recibe la visita anual de su gran admirador el rey Gustavo de Suecia.

«El borracho», por ejemplo, este personaje triste y soñador -como dice Lotheque procede del peregrino, del poeta y del obrero, tiene una formación espiritual muy parecida a la de «La Communiante».

Aunque tan distintos en su técnica, el mecanismo ideológico de estas dos obras es muy semejante. El escepticismo y un fino sentimiento irónico lleva a María a jugar con el equívoco. En este cuadro nos enseña un hombre de fisonomía brutal, con su mano inmensa y ruda ávida de vino, mientras un barril del fondo nimba, por superposición, su rostro embrutecido. Para una inteligencia fina y un espíritu penetrante como el de María no hay nada absolutamente concreto. Sus personajes, como los de Dostoïevski, tienen una complejidad humana y conmovedora. Por primera vez en lo plástico nos presenta María Blanchard la dualidad del alma humana.

Su sentimiento irónico, nunca exento de ternura, se revela también «El niño del helado» (L'enfant à la glace). Un colegial con su traje de domingo viene probablemente del colegio. Acaban de otorgarle un premio honorífico que deja caer con indiferencia ante la tentación de un helado que se dispone a comer, no sin preocuparse antes de su corbata. En su mirada inteligente y reflexiva se adivina un prematuro escepticismo y un amor a lo positivo. ¿Para qué sirve una corona de laurel? ¿No es preferible saborear una golosina?

El pomposo carrito del helado al cual asoma la infancia misma golosa y atrevida, el fondo de la calle con su minucioso empedrado, la línea del horizonte tan elevada y los minúsculos árboles, están impregnados de una fuerte personalidad que recuerda en cierto modo a los primitivos.

María Blanchard trabaja siempre en el interior de su taller. Jamás al aire libre ni ante modelo. Frente a la tela en blanco busca en su memoria la forma y el color y extrae de su fina sensibilidad la expresión de sus criaturas.

Su memoria visual es sorprendente. En una ocasión dice al terminar uno de sus cuadros: «Es una viejecita que vi hace doce años...» Otra vez su modelo es un niño que se cruza ante ella por la calle cuando va a misa, y esa visión que hiere su retina por cualquier motivo sensible queda grabada en ella como una fijeza de instantánea.

1 Recogemos en este texto un extracto del libro de María Campo Alange María Blanchard, Madrid: Editorial Hauser y Menet, 1944. 
Tiene para sus criaturas una fisonomía propia. Los personajes de sus cuadros pertenecen todos a una misma raza. Nariz ancha, labios gruesos, tiernamente sensuales; ojos tristes, brillantes; cuello corto con tendencia a suprimirlo totalmente valiéndose de una posición adecuada, como en la «Joven campesina», «La toilette», «La niña del collar», «La comida» y tantos otros. Obedece así a la ley psicológica tan conocida, que crea en el artista la tendencia a reproducir en sus obras sus propios defectos físicos.

No pretende, sin embargo, acercarnos a un tipo racial determinado ni aun menos regional. No tiene preferencia por un ambiente, por unas costumbres; no siente, como Gauguin, la influencia de Bretaña, ni de Tahíti, ni de ningún otro lugar del mapa. Sólo marca una inclinación por los humildes, pero no intenta con ello darnos una lección social, pues su obra carece, por otra parte, de anecdotismo. María Blanchard nos pinta pobres seres meditativos, bien sean hombres, mujeres o niños, envueltos muchos de ellos en una atmósfera de un ridículo próximo a la ternura.

A través de la dulce escuela de París, su pintura conserva el carácter típicamente español de violencia y dramatismo.

Su dibujo es duro por ser demasiado fuerte. Su colorido, violento. No teme emplear el negro puro.

Hace brillar los objetos sin preocupación de la materia propia, y a veces la luz se descompone sobre ellos hasta llegar a producir el color en sus elementos primarios, azul, rojo, amarillo.

En cuanto a sus conocimientos técnicos, según el eminente crítico Waldemar George, «María Blanchard es de los que comprenden la vanidad de un arte escuetamente tradicional». Y añade:

«Mas si repudia el neoclasicismo, si adapta sus medios de expresión a su estilo, quiere beneficiarse de la aportación al pasado. Quiere decir que conoce perfectamente su oficio de pintor y de dibujante, y si evita hacer exhibición de sus conocimientos, los utiliza de una manera oportuna. La anatomía y la ciencia de la perspectiva no tiene secretos para esta artista, cuidadosa de realización ${ }^{2}$.

Mientras tanto, Rosemberg juega con ella como un gato con un pajarillo. María visita ilusionada su galería una y otra vez y allí espera durante horas enteras mientras el hábil comerciante atiende a sus ricos compradores. Luego se acerca a la pobre artista. Esta tiembla de emoción. ¿Qué desea? ¡Ah! ¿Para hacerle ver su producción? ¡Está tan ocupado! Y hay tantos pintores interesantes en estos momentos: Utrillo, Modigliani, Picasso; en fin, ya pasará algún día por su estudio. ¿Cuándo...? Perdone, señorita, un cliente me reclama. Y María vuelve a su estudio desalentada, inquieta, creyéndose poco interesante para este hombre, que, sin embargo, se llevará poco a poco lo mejor de su obra con un aire de indiferencia fríamente calculada para no despertar la ambición de esta pobre mujer.

Prefiere, sin embargo, María Blanchard la sequedad del comerciante al cálido elogio y la ferviente admiración del «amateur». 
Vender sus obras es siempre una tragedia para ella, pero, al menos, el trato con un comerciante es algo preciso en que no debe mezclarse el sentimentalismo. Se trata de un hombre frío y calculador que compra lo que sabe que ha de revender a mayor precio. ¡Pero el aficionado! ¡Esos entusiasmos, esas exclamaciones de sorpresa, de admiración, esas largas contemplaciones silenciosas todavía más elocuentes! No. Un extraño pudor se despierta en esta mujer ante la admiración de su obra y se resiste a entregarla como si al vender un lienzo prostituyese su arte. A veces sostiene luchas interminables como aquella con un joven escritor americano, que quedó como hipnotizado ante la expresión extraña de su pintura, y hasta tal punto produce impresión en él que permanece una hora sin hablar delante de una de sus «maternidades», creyéndosele loco. Pues bien; este hombre, que amó la expresión artística de María hasta el éxtasis, se tuvo que marchar sin conseguir que le vendiera nada.

Todos los argumentos eran buenos para disuadirle. Todavía no estaba terminado su cuadro, pero, además, no era la suya una pintura «interesante» y, sobre todo, sería una mala colocación de dinero, estaba segura de ello, y de que al día siguiente, si llegaba a comprarle algo, estaría arrepentido de haberlo hecho. 